\title{
Comparing Spatial Associations of Commuting versus Recreational Ridership Captured by the Strava Fitness App
}

\author{
Jaimy Fischer ${ }^{1}$ (D), Trisalyn Nelson ${ }^{2}$ (D) Meghan Winters ${ }^{1}$ (D) \\ ${ }^{1}$ Faculty of Health Sciences, Simon Fraser University, ${ }^{2}$ School of Geographical Sciences and Urban Planning, Arizona State University \\ Keywords: urban planning, strava, mobility, big data, bicycling, bias correction, active transportation \\ https://doi.org/10.32866/001c.16710
}

Transport Findings

\begin{abstract}
Strava Metro data are used in bicycle planning, but there are concerns it overrepresents fitness activity. The data include a commute label, but spatial patterns of commuting versus recreational ridership are underexplored. Using spatial regression, we compare associations of Strava ridership by trip type. Commuting was associated with areas with more on-street infrastructure, universities, and higher bicycle crash density. Recreational ridership was higher in areas with older populations, more hills and major roads, and lower intersection density. Both trip purposes tended to be in areas with regional trails, off-street infrastructure, higher bicycle mode share, bridges, and proximity to the ocean.
\end{abstract}

\section{Research Question and Hypothesis}

Strava Metro data are being used in bicycling research but are critiqued for bias-both in demographic and trip type-related to who and how the app is used. How well Strava ridership reflects overall bicycle ridership depends on locational factors, for example, how busy a street is, if bicycling infrastructure exists, and safety (Livingston et al. 2020; Nelson et al. 2020). Bias can be addressed by using models that link Strava ridership to counts of all bicyclists, and adjusting for geographic covariates (Jestico, Nelson, and Winters 2016; Roy et al. 2019). Strava data also include a commute label, which may better align with overall ridership. However, there is limited understanding of how Strava trips labelled as commute versus recreation differ in terms of representativeness. Our goal is to understand how the commute label impacts data representativeness by comparing geographic covariates associated with Strava commute and recreational ridership. We hypothesize that commute and recreational ridership samples will be associated with different areas of a city and anticipate that, compared to recreational ridership, Strava data labelled as commute trips better represent overall ridership.

\section{Methods and Data}

\section{Study area}

The study area is the census metropolitan area (CMA) of Victoria, British Columbia, Canada, with a population of $~ 367,770$ (Statistics Canada 2016) and a bicycle mode share of 6.6\%, the highest among Canada's CMAs (Statistics Canada 2017). Victoria has over $200 \mathrm{~km}$ of bicycling infrastructure including $\sim 100 \mathrm{~km}$ of regional trails. These paths are the backbone of the bicycling network and are heavily used for both commuting and recreation. 


\section{Data and Analysis}

We used spatial regression to identify associations between sociodemographic, network, and built and natural environment characteristics for each trip type, and for the pooled sample. The Strava Metro data are from January 1, 2016 September 30, 2017, and include a spatial file representing the street network and tabular data with aggregate activity counts for each segment. An attribute provided by Strava Metro identifies the count of activities on each segment that were commute trips. We also had area-level summary statistics on the number of unique app users, age-gender distribution, and trip characteristics.

The geographical unit of analysis was the Statistics Canada Dissemination Area (DA; 400-700 people; $n=534$ ). We operationalized Strava ridership as bicycle kilometers traveled (BKT), calculated by multiplying the activity count on each road segment by the segment length and summing the products for each DA (Hochmair, Bardin, and Ahmouda 2019). We standardized BKT by DA total road length and mapped results for each trip type compared to the pooled sample (Figures $\underline{1}$ and $\underline{2}$ ). Geographic covariates were identified based on previous studies using Strava data, relevance in bicycling studies using conventional data, or local importance to bicycling (Table 1).

We constructed three spatial error models using GeoDa 1.14 (Anselin 2019) and defined spatial neighbors using queen contiguity. The spatial error models use a Maximum Likelihood approach and treat spatially correlated residuals as a nuisance variable (Anselin 2009). The first and second models predicted DA commute and recreational BKT and the third predicted BKT for the pooled Strava sample.

Spatial analyses of areal data are often influenced by spatial autocorrelation (SAC) - the tendency for neighboring areas to have similar values. In ordinary least squares regression, spatial effects can lead to unreliable results as standard assumptions are violated (Anselin 2009). Spatial regression approaches include spatial lag and spatial error models, and model diagnostics indicate which is appropriate (Anselin 2009). We quantified SAC using Moran's $\mathrm{I}_{i}$, and used the Robust Lagrange Multiplier (LM) statistic to select the appropriate spatial regression model; the rule of thumb is to choose the model (lag or error) with the most significant LM test statistic (Anselin 2009). We also considered model fit ( $\mathrm{R}^{2}$ and AIC).

\section{Findings}

In Victoria, there were 12,971 unique Strava app users and 315,200 activities; $49 \%(\mathrm{n}=155,252)$ of activities were identified as commutes. Men accounted for $74.9 \%(n=9226)$ of app users, and $64 \%$ of users $(n=7,958)$ were under age 55. Table 2 shows BKT descriptive statistics. Notably, BKT for recreational trips comprised nearly two-thirds of the total BKT (63.5\%); so, while there were approximately equal numbers of commute and recreational activities, the recreational trips tended to be longer in distance. 
Table 1. Geographic covariates used to model Strava bicycle kilometers travelled (BKT) at the dissemination area (DA) level

\begin{tabular}{|c|c|c|c|}
\hline Variable & Operationalization & Relevance & Source \\
\hline \multicolumn{4}{|l|}{ Sociodemographic } \\
\hline $\begin{array}{c}\text { Bike } \\
\text { commuters }\end{array}$ & $\begin{array}{l}\% \text { of the } \\
\text { population who } \\
\text { bicycle to work }\end{array}$ & $\begin{array}{l}\text { Crowdsourced ridership patterns may be similar in areas } \\
\text { where more people bicycle to work (Conrow et al. 2018) }\end{array}$ & $\begin{array}{l}\text { Statistics } \\
\text { Canada } 2016 \\
\text { Census }\end{array}$ \\
\hline $\begin{array}{c}\text { Male } \\
\text { population }\end{array}$ & $\begin{array}{l}\% \text { of the } \\
\text { population who is } \\
\text { male }\end{array}$ & $\begin{array}{l}\text { Men associated with higher levels of bicycling (Aldred, } \\
\text { Woodcock, and Goodman 2016) and Strava app usership }\end{array}$ & $\begin{array}{l}\text { Statistics } \\
\text { Canada } 2016 \\
\text { Census }\end{array}$ \\
\hline $\begin{array}{l}\text { Median } \\
\text { household income }\end{array}$ & Quintile & $\begin{array}{l}\text { Higher and lower income associated with more bicycling } \\
\text { (Pucher and Buehler 2006; Winters et al. 2007) }\end{array}$ & $\begin{array}{l}\text { Statistics } \\
\text { Canada } 2016 \\
\text { Census }\end{array}$ \\
\hline $\begin{array}{l}\text { Post- } \\
\text { secondary } \\
\text { education }\end{array}$ & $\begin{array}{l}\% \text { of the } \\
\text { population with a } \\
\text { post-secondary } \\
\text { degree or diploma }\end{array}$ & $\begin{array}{l}\text { Those with higher education more likely to bicycle (Winters et } \\
\text { al. 2010) }\end{array}$ & $\begin{array}{l}\text { Statistics } \\
\text { Canada } 2016 \\
\text { Census }\end{array}$ \\
\hline $\begin{array}{l}\text { Under } 15 \\
\text { years }\end{array}$ & $\begin{array}{l}\% \text { of the } \\
\text { population under } \\
\text { age } 15\end{array}$ & $\begin{array}{l}\text { Children and older adults associated with lower rates of } \\
\text { bicycling (Aldred, Woodcock, and Goodman 2016; Pucher et al. } \\
\text { 2011) }\end{array}$ & $\begin{array}{l}\text { Statistics } \\
\text { Canada } 2016 \\
\text { Census }\end{array}$ \\
\hline $\begin{array}{l}\text { Over } 65 \\
\text { years }\end{array}$ & $\begin{array}{l}\% \text { of the } \\
\text { population over } \\
\text { age } 65\end{array}$ & & $\begin{array}{l}\text { Statistics } \\
\text { Canada } 2016 \\
\text { Census }\end{array}$ \\
\hline $\begin{array}{l}\text { Visible } \\
\text { minority }\end{array}$ & $\begin{array}{l}\% \text { of the } \\
\text { population who is } \\
\text { a visible minority }\end{array}$ & $\begin{array}{l}\text { Higher neighborhood \% of whites associated with more } \\
\text { bicycling (Chen, Zhou, and Sun 2017); lower rates of bicycling } \\
\text { investment in high \% visible minority neighborhoods (Braun, } \\
\text { Rodriguez, and Gordon-Larsen 2019) }\end{array}$ & $\begin{array}{l}\text { Statistics } \\
\text { Canada } 2016 \\
\text { Census }\end{array}$ \\
\hline \multicolumn{4}{|l|}{ Network } \\
\hline $\begin{array}{l}\text { Arterial, } \\
\text { collector, local } \\
\text { roads }\end{array}$ & $\begin{array}{l}\% \text { of the total } \\
\text { neighborhood } \\
\text { road network in } \\
\text { each functional } \\
\text { road class }\end{array}$ & $\begin{array}{l}\text { Road class and density influence bicycling safety and route } \\
\text { choice (Fraser and Lock 2011; Winters et al. 2010) }\end{array}$ & $\begin{array}{l}\text { Capital } \\
\text { Regional } \\
\text { District }\end{array}$ \\
\hline $\begin{array}{l}\text { On-street } \\
\text { bicycle } \\
\text { infrastructure }\end{array}$ & $\begin{array}{l}\text { \% of the total } \\
\text { neighborhood } \\
\text { road network with } \\
\text { on-street } \\
\text { infrastructure }\end{array}$ & $\begin{array}{l}\text { Bicycling infrastructure associated with higher rates of } \\
\text { bicycling (Fraser and Lock 2011); off-street paths associated } \\
\text { with Strava ridership (Hochmair, Bardin, and Ahmouda 2019) }\end{array}$ & $\begin{array}{l}\text { Capital } \\
\text { Regional } \\
\text { District }\end{array}$ \\
\hline $\begin{array}{l}\text { Off-street } \\
\text { bicycle } \\
\text { infrastructure }\end{array}$ & $\begin{array}{l}\% \text { of the total } \\
\text { neighborhood } \\
\text { road network with } \\
\text { off-street } \\
\text { infrastructure }\end{array}$ & & $\begin{array}{l}\text { Capital } \\
\text { Regional } \\
\text { District }\end{array}$ \\
\hline Regional trail & $\begin{array}{l}\text { Binary variable, } 1 \\
\text { if regional trail } \\
\text { network passes } \\
\text { through DA }\end{array}$ & Important cycling infrastructure in the Victoria region & $\begin{array}{l}\text { Capital } \\
\text { Regional } \\
\text { District }\end{array}$ \\
\hline $\begin{array}{l}\text { Intersection } \\
\text { density }\end{array}$ & $\begin{array}{l}\text { Count of } \\
\text { intersections in } 1 \\
\mathrm{~km} \text { of DA centroid }\end{array}$ & $\begin{array}{l}\text { Higher intersection density associated with more bicycling } \\
\text { (Winters et al. 2010) }\end{array}$ & $\begin{array}{l}\text { Canadian } \\
\text { Active Living } \\
\text { Environments } \\
\text { (Can-ALE) }\end{array}$ \\
\hline \multicolumn{4}{|l|}{$\begin{array}{l}\text { Built \& natural } \\
\text { environment }\end{array}$} \\
\hline Bridge & $\begin{array}{l}\text { Binary variable, } 1 \\
\text { if DA has a major } \\
\text { bridge }\end{array}$ & $\begin{array}{l}\text { Bridges are important links between different parts of a street } \\
\text { network (Boss et al. 2018; Hochmair, Bardin, and Ahmouda } \\
\text { 2019) }\end{array}$ & $\begin{array}{l}\text { Capital } \\
\text { Regional } \\
\text { District }\end{array}$ \\
\hline $\begin{array}{l}\text { Distance to } \\
\text { university }\end{array}$ & $\begin{array}{l}\text { Distance from DA } \\
\text { centroid to } \\
\text { nearest university }\end{array}$ & $\begin{array}{l}\text { Bicycling is higher around major destinations like universities } \\
\text { (Krizek, Barnes, and Thompson 2009) }\end{array}$ & $\begin{array}{l}\text { British } \\
\text { Columbia } \\
\text { Open Data } \\
\text { Catalogue }\end{array}$ \\
\hline Steep slopes & $\%$ of roads with & Steep slopes impact route choice in utilitarian cycling and & GeoBC \\
\hline
\end{tabular}




\begin{tabular}{|c|c|c|c|}
\hline Variable & Operationalization & Relevance & Source \\
\hline & $\begin{array}{l}\text { maximum slope } \\
>5 \% \text { (steep) }\end{array}$ & $\begin{array}{l}\text { linked to more Strava bicycling (Winters et al. 2010; Lee and } \\
\text { Sener 2019) }\end{array}$ & \\
\hline $\begin{array}{l}\text { Distance to } \\
\text { shore }\end{array}$ & $\begin{array}{l}\text { Distance from DA } \\
\text { centroid to } \\
\text { shoreline }\end{array}$ & $\begin{array}{l}\text { Water bodies associated with more bicycling and Strava } \\
\text { ridership (Chen, Zhou, and Sun 2017; Hochmair, Bardin, and } \\
\text { Ahmouda 2019) }\end{array}$ & $\begin{array}{l}\text { Statistics } \\
\text { Canada } 2016 \\
\text { Census }\end{array}$ \\
\hline \multicolumn{4}{|l|}{ Safety } \\
\hline $\begin{array}{l}\text { Bicycle crash } \\
\text { density }\end{array}$ & $\begin{array}{l}\text { \# of crashes } \\
\text { divided by road } \\
\text { length }\end{array}$ & $\begin{array}{l}\text { Route choice affected by perceptions of safety (Winters et al. } \\
\text { 2012) }\end{array}$ & $\begin{array}{l}\text { Insurance } \\
\text { Corporation } \\
\text { of British } \\
\text { Columbia }\end{array}$ \\
\hline
\end{tabular}

Table 2. Descriptive statistics for Strava ridership volumes (bicycle kilometers traveled, BKT) in 534 dissemination areas (DA)

\begin{tabular}{lllllll}
\hline Activity Type & Mean & Median & SD & Min & Max & Total \\
\hline Commute BKT & 776.1 & 529.7 & 853.9 & 14.6 & $12,041.1$ & $414,456.5$ \\
Recreational BKT & $1,354.2$ & 821.9 & $1,610.4$ & 46.0 & $12,454.6$ & $723,148.5$ \\
Pooled BKT & $2,130.4$ & $14,114.1$ & $2,308.7$ & 67.9 & $24,495.7$ & $1,137,605.0$ \\
\hline
\end{tabular}

Strava activities labelled as commutes showed higher ridership levels in DAs that were closer to universities, had more on-street infrastructure, and higher bicycle crash densities. Recreational activities showed higher ridership in DAs with older populations, more hills and major roads (arterial and collector), and lower intersection density. Strava activities for commute or recreation showed similar levels of ridership in DAs with regional trails, more off-street infrastructure, higher bicycle mode share, bridges, and closer proximity to the ocean.

Using Strava data labelled as commute activities, instead of a pooled sample, may mitigate bias in Strava data and better represent ridership patterns of people of all ages and abilities. When using only the commute activities, we saw different spatial patterning in ridership and found that activities tended to be in areas with bicycle infrastructure, lower levels of safety, and around universities. Recreation activities were more common in areas with major roads, steep slopes, and lower intersection density-factors that are typically less preferred and less safe for bicycling (Teschke et al. 2012; Winters et al. 2010). Other important covariates were common across commute and recreational trips (regional trails, off-street infrastructure, bicycle mode share, bridges, and proximity to the ocean) and would be selected from either the commute or pooled sample. This suggests that if a planning exercise aimed to model overall ridership using Strava data and geographic covariates, a distinct set of covariates would be selected if only the commute data were used. In Victoria, commuting accounted for $49 \%$ of all Strava activities and 36.5\% of the total distance (e.g., BKT). From other Strava analyses we learn the proportion of commute trips varies across cities (e.g., 21\% in El Paso, Texas (Lee and Sener 2019), 85\% 


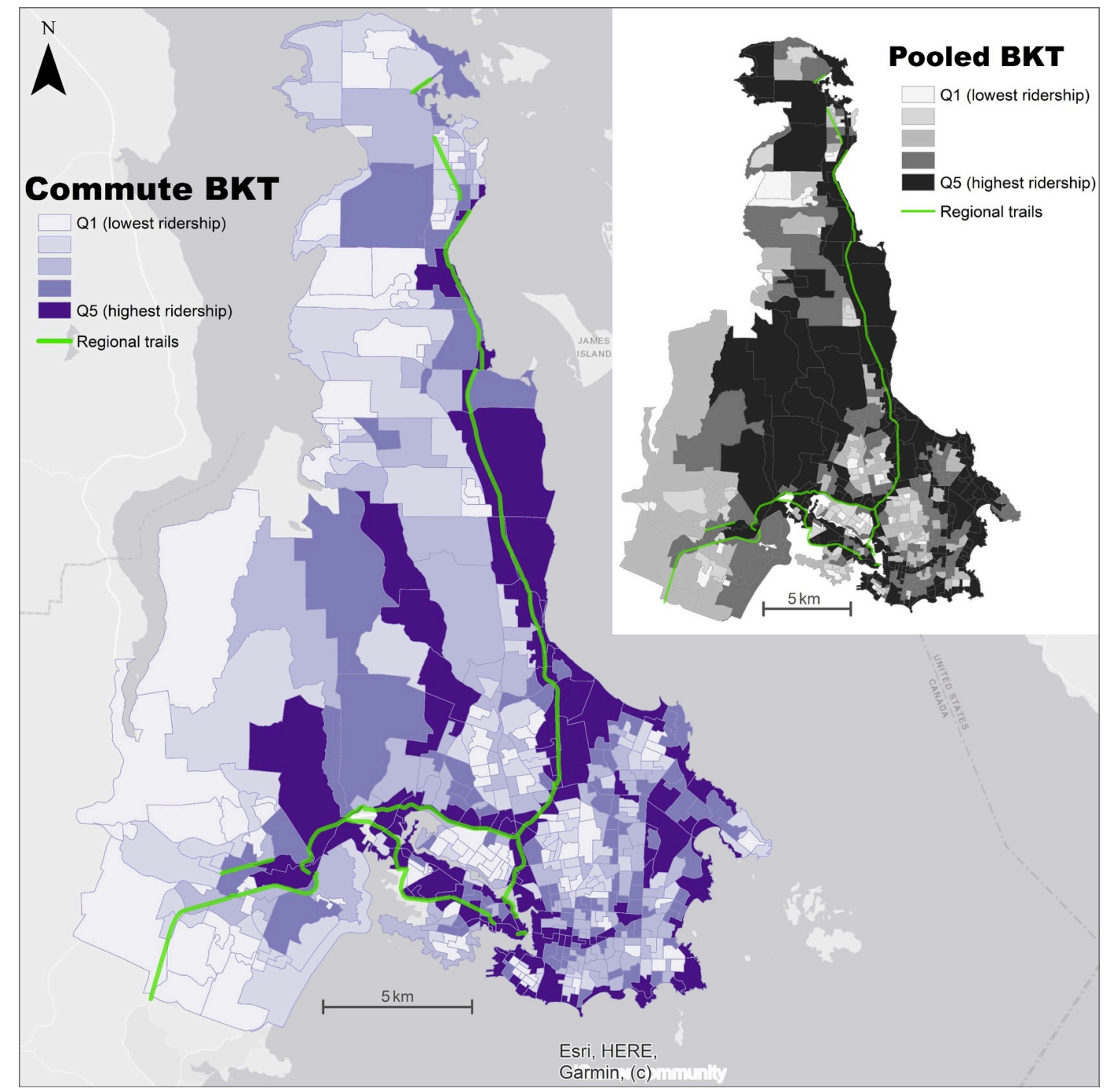

Figure 1. Strava commute BKT compared to the pooled sample (quintiles) in DAs ( $\mathbf{n}=534)$.

in Milan, Italy (Sunde 2019). If interested in modeling all ages and abilities ridership, researchers and practitioners should consider using only commute data, at least in cities where the sample is sufficiently large.

\section{Acknowledgements}

The authors would like to acknowledge Strava for providing the data. 


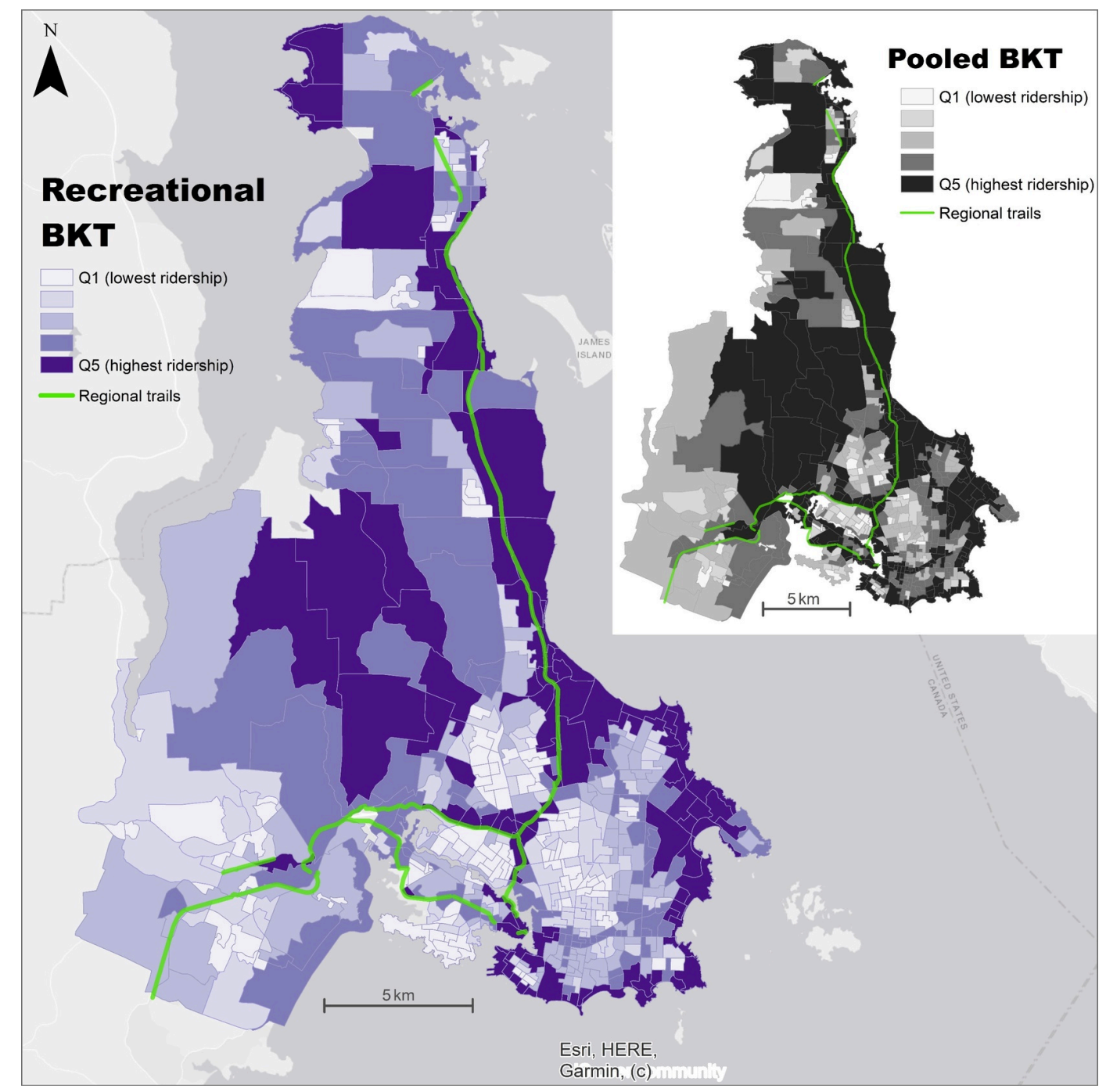

Figure 2. Strava recreational BKT compared to the pooled sample (quintiles) in DAs $(n=534)$. 
Table 3. Spatial regression estimates of DA Strava ridership (bicycle kilometers traveled, BKT) for trips labeled commute, recreation, and the pooled sample (all data combined).

\begin{tabular}{|c|c|c|c|}
\hline Outcome & Commute BKT & Recreational BKT & Pooled BKT \\
\hline \multicolumn{4}{|l|}{ Spatial dependence diagnostics } \\
\hline Moran's li & $8.7^{* * *}$ & $13.9^{* * *}$ & $12.2^{* * *}$ \\
\hline Robust Lagrange Multiplier (lag) & 2.7 & $14.3^{* * *}$ & $6.7^{* *}$ \\
\hline Robust Lagrange Multiplier (error) & $12.2^{* * *}$ & $9.0^{*}$ & $13.2^{* * *}$ \\
\hline $\mathrm{R}^{2}(\operatorname{lag})$ & 0.6 & 0.6 & 0.6 \\
\hline $\mathrm{R}^{2}$ (error) & 0.6 & 0.6 & 0.6 \\
\hline AIC (lag) & 8305 & 9019 & 9422 \\
\hline AIC (error) & 8289 & 8986 & 9389 \\
\hline \multicolumn{4}{|l|}{ Geographic covariates } \\
\hline \multicolumn{4}{|l|}{ Sociodemographic } \\
\hline Bike commuters & $2120.6^{* * *}$ & $4861.2^{* * *}$ & $7030.5^{* * *}$ \\
\hline Male population & 1793.9 & 3542.4 & 5341.3 \\
\hline Median household income & 37.6 & 27.6 & 69.0 \\
\hline Post-secondary education & 616.8 & 916.4 & 1489.9 \\
\hline Under 15 years & -1182.7 & -237.5 & -1297.0 \\
\hline Over 65 years & 574.2 & $2015.9^{* *}$ & $2623.0^{*}$ \\
\hline Visible minority & -291.2 & -850.6 & -1152.6 \\
\hline \multicolumn{4}{|l|}{ Street network } \\
\hline Arterial road & 608.0 & $3348.4^{* * *}$ & $4071.2^{* * *}$ \\
\hline Collector road & 211.0 & $1847.6^{* *}$ & $2117.4^{*}$ \\
\hline Local road & -245.2 & 277.1 & 39.2 \\
\hline On-street bicycle infrastructure & $1572.9^{* * *}$ & 585.6 & $2087.9^{*}$ \\
\hline Off-street bicycle infrastructure & $2589.7^{* * *}$ & $2904.0^{* *}$ & $5488.3^{* * *}$ \\
\hline Regional trail network & $759.9^{* * *}$ & $734.7^{* * *}$ & $1475.0^{* * *}$ \\
\hline Intersection density & -3.2 & $-20.9^{* * *}$ & $-24.2^{* * *}$ \\
\hline \multicolumn{4}{|l|}{ Built and natural environment } \\
\hline Bridge & $765.9^{* * *}$ & 701.1* & $1450.0^{* *}$ \\
\hline Proximity to university & $-29.0^{*}$ & -65.4 & $-96.8^{*}$ \\
\hline Steep slopes (more hills) & 214.1 & $746.0^{*}$ & $927.9^{*}$ \\
\hline Distance to shore & $-202.4^{* * *}$ & $-509.7^{* * *}$ & $-720.6^{* * *}$ \\
\hline \multicolumn{4}{|l|}{ Safety } \\
\hline Bicycle crash density & $93.5^{* * *}$ & 52.7 & $140.1^{*}$ \\
\hline Constant & -637.3 & -1087.3 & -1697.2 \\
\hline Spatial error (Lambda) & $0.5^{* * *}$ & $0.8^{* * *}$ & $0.7^{* * *}$ \\
\hline
\end{tabular}

${ }^{* * *} \mathrm{p}<0.001,{ }^{* *} \mathrm{p}<.01,{ }^{*} \mathrm{p}<0.05$ 


\section{REFERENCES}

Aldred, Rachel, James Woodcock, and Anna Goodman. 2016. "Does More Cycling Mean More Diversity in Cycling?” Transport Reviews: Cycling As Transport 36 (1): 28-44. https://doi.org/ $\underline{10.1080 / 01441647.2015 .1014451 .}$.

Anselin, L. 2009. "Spatial Regression.” In The SAGE Handbook of Spatial Analysis, edited by S. Fotheringham and P. Rogerson, 255-75. London: Sage Publications. https://doi.org/10.4135/ 9780857020130 .

-_-. 2019. GeoDa (1.14) [Software]. https://geodacenter.github.io/.

Boss, Darren, Trisalyn Nelson, Meghan Winters, and Colin J. Ferster. 2018. "Using Crowdsourced Data to Monitor Change in Spatial Patterns of Bicycle Ridership." Journal of Transport $\mho^{2}$ Health 9 (June): 226-33. https://doi.org/10.1016/j.jth.2018.02.008.

Braun, Lindsay M., Daniel A. Rodriguez, and Penny Gordon-Larsen. 2019. "Social (in)Equity in Access to Cycling Infrastructure: Cross-Sectional Associations between Bike Lanes and Area-Level Sociodemographic Characteristics in 22 Large U.S. Cities." Journal of Transport Geography 80 (October): 102544. https://doi.org/10.1016/j.jtrangeo.2019.102544.

Chen, Peng, Jiangping Zhou, and Feiyang Sun. 2017. "Built Environment Determinants of Bicycle Volume: A Longitudinal Analysis." Journal of Transport and Land Use 10 (1): 655-74. https://doi.org/10.5198/jtlu.2017.892.

Conrow, Lindsey, Elizabeth Wentz, Trisalyn Nelson, and Christopher Pettit. 2018. "Comparing Spatial Patterns of Crowdsourced and Conventional Bicycling Datasets.” Applied Geography 92 (March): 21-30. https://doi.org/10.1016/j.apgeog.2018.01.009.

Fraser, Simon D.S., and Karen Lock. 2011. "Cycling for Transport and Public Health: A Systematic Review of the Effect of the Environment on Cycling." European Journal of Public Health 21 (6): 738-43. https://doi.org/10.1093/eurpub/ckq145.

Hochmair, Hartwig H., Eric Bardin, and Ahmed Ahmouda. 2019. "Estimating Bicycle Trip Volume for Miami-Dade County from Strava Tracking Data." Journal of Transport Geography 75 (February): 58-69. https://doi.org/10.1016/j.jtrangeo.2019.01.013.

Jestico, Ben, Trisalyn Nelson, and Meghan Winters. 2016. "Mapping Ridership Using Crowdsourced Cycling Data." Journal of Transport Geography 52 (April): 90-97. https://doi.org/ 10.1016/j.jtrangeo.2016.03.006.

Krizek, Kevin J., Gary Barnes, and Kristin Thompson. 2009. "Analyzing the Effect of Bicycle Facilities on Commute Mode Share over Time." Journal of Urban Planning and Development 135 (2): 66-73. https://doi.org/10.1061/(asce)0733-9488(2009)135:2(66).

Lee, Kyuhyun, and Ipek N. Sener. 2019. "Understanding Potential Exposure of Bicyclists on Roadways to Traffic-Related Air Pollution: Findings from El Paso, Texas, Using Strava Metro Data." International Journal of Environmental Research and Public Health 16 (3): 371. https://doi.org/10.3390/ijerph16030371.

Livingston, Mark, David McArthur, Jinhyun Hong, and Kirstie English. 2020. "Predicting Cycling Volumes Using Crowdsourced Activity Data." Environment and Planning B: Urban Analytics and City Science, May, 1-17. https://doi.org/10.1177/2399808320925822.

Nelson, Trisalyn A., Avipsa Roy, Colin J. Ferster, J. Fischer, V. Brum-Bastos, and Meghan Winters. 2020. "Best Practices for Modeling Bicycle Ridership with Crowdsourced Data." 
Pucher, John, and Ralph Buehler. 2006. "Why Canadians Cycle More than Americans: A Comparative Analysis of Bicycling Trends and Policies.” Transport Policy 13 (3): 265-79. https://doi.org/10.1016/j.tranpol.2005.11.001.

Pucher, John, Ralph Buehler, Dafna Merom, and Adrian Bauman. 2011. "Walking and Cycling in the United States, 2001-2009: Evidence from the National Household Travel Surveys.” American Journal of Public Health 101 (S1): S310-17. https://doi.org/10.2105/ajph.2010.300067.

Roy, Avipsa, Trisalyn A. Nelson, A. Stewart Fotheringham, and Meghan Winters. 2019. "Correcting Bias in Crowdsourced Data to Map Bicycle Ridership of All Bicyclists." Urban Science 3 (2): 62 . https://doi.org/10.3390/urbansci3020062.

Statistics Canada. 2016. "Victoria [Census Metropolitan Area], British Columbia and British Columbia [Province] (Table)." Census Profile. 2016 Census. Statistics Canada Catalogue no. 98-316-X2016001. https://www12.statcan.gc.ca/census-recensement/2016/dp-pd/prof/ index.cfm? Lang=E.

- - . 2017. "Census in Brief: Commuters Using Sustainable Transportation in Census Metropolitan Areas.” https://www12.statcan.gc.ca/census-recensement/2016/as-sa/98-200-x/ 2016029/98-200-x2016029-eng.cfm.

Sunde, E. 2019. "Tracking the Rise of Bike Commuting around the World.” Medium. https://medium.com/strava-metro/tracking-the-rise-of-bike-commuting-around-theworld-5bada94585c5.

Teschke, Kay, M. Anne Harris, Conor C. O. Reynolds, Meghan Winters, Shelina Babul, Mary Chipman, Michael D. Cusimano, et al. 2012. "Route Infrastructure and the Risk of Injuries to Bicyclists: A Case-Crossover Study.” American Journal of Public Health 102 (12): 2336-43. https://doi.org/10.2105/ajph.2012.300762.

Winters, Meghan, Shelina Babul, H. J. E. H. Becker, Jeffrey R. Brubacher, Mary Chipman, Peter Cripton, Michael D. Cusimano, et al. 2012. "Safe Cycling: How Do Risk Perceptions Compare With Observed Risk?” Canadian Journal of Public Health 103 (S3): S42-47. https://doi.org/ $10.1007 / \mathrm{bf} 03403834$.

Winters, Meghan, Michael Brauer, Eleanor M. Setton, and Kay Teschke. 2010. "Built Environment Influences on Healthy Transportation Choices: Bicycling versus Driving." Journal of Urban Health 87 (6): 969-93. https://doi.org/10.1007/s11524-010-9509-6.

Winters, Meghan, Melissa C. Friesen, Mieke Koehoorn, and Kay Teschke. 2007. "Utilitarian Bicycling. A Multilevel Analysis of Climate and Personal Influences." American Journal of Preventive Medicine 32 (1): 52-58. https://doi.org/10.1016/j.amepre.2006.08.027. 